\title{
〈速 報〉
}

各種肝疾患ならびに供血者における Arai

抗原 (a new serum-antigen), 抗体の検索

\begin{tabular}{|c|c|c|c|c|c|c|c|}
\hline 田 & 精市 & 小松 & 敬直 & 長田 & 敦夫 & 清沢 & 研道 \\
\hline 羽 & 賢浩 & 小池以 & bり子 & 佐原 & 就 & 古川 & 賢一 \\
\hline & 義浩 & 山村 & 伸吉 & 小田 & 正幸* & 藤末 & 順 - \\
\hline$\frac{w}{F}$ & 恵 & 滝本 & 義一 & 守本 & 富昭** & & 品" \\
\hline
\end{tabular}

前報1)に扎いて著者らは急性 B 型肝炎の 1 患者血清と 慢性肝炎の 1 患者血清との間に, 既知の HBV 関連抗原 ・抗体系と全く異なる新しい沈降線をみとめ，その抗原 について検討し Arai 抗原と命名したことを報告した。 今回は各種の肝疾患々者ならびに供血者に持ける Arai 抗原・抗体の検索を行ったのでその成績を報告する。

対象：信州大学第 2 内科括よび関連病院に拈いて，腹 腔鏡，肝生検，剖検および一部は血清の $\alpha \mathrm{FP}$ の検索によ り診断された，原発性肝癌 4.0 例, 肝硬変 52 例, 慢性肝炎 活動型45例, 同非活動型33例, 急性肝炎44例の計 214 例 と, 血中 HBs-Ag 陽性供血者95例, 同陰性供血者50例で てある. 被検血清は通常のごとく採血、分離し, $-20^{\circ} \mathrm{C}$ に保存したものを用いた。

方法 : 既報” のごとくArai 抗原・抗体を含むそれぞ れの reference 血清および被検血清を lyphogel で約 $3 〜$ 5 倍に濃縮したものを用いて MO 法により抗原, 抗体を 検索した. MO 法には $0.9 \%$ agarose gel を使用した.

成績 : 各種肝疾患々者ならびに供血者血清における Arai 抗原，抗体の陽性率を表 Iに示した。抗原は原発 珄肝癌で $37.5 \%$ ともっと高率に検出された．急性肝炎 例では36.4\%に検出されたが，回復期には陰性化する傾 向がみられた，しかし一部の症例では回復期後において るな特続的に陽性であった. 肝硬変例では25.0\%，慢 性肝炎活動型 $20.0 \%$, 同非活動型18.2\%にそれぞれ本抗 原が検出された。

供血者では HBs-Ag 陰性例で全例本抗原も陰性であっ たが, HB-Ags陽性例では95例中の 2 例, $2.1 \%$ に本抗原 が捈出された。抗体の陽性率は，急性肝炎 $11.4 \%$, 慢性 肝炎非活動型 $6.1 \%$, 肝硬変 $5.8 \%$ ，肝癌 $2.5 \%$ であっ た。な特肝疾患に挌いては血中 HBs-Ag, $\alpha \mathrm{FP}$ の有無と Arai 抗原, 抗体の陽性率との間には関嘾性は全くみら れなかった。

考案：既報ならびに上述成績の項で述べたごとく， Arai 抗原は急性 B 型肝炎急性期 の患者血清中に発見さ れた抗原であるが, HBs-Ag, e 抗原とは抗原性を全く異 にし，かつ各種肝疾患に扎いて HBs-Ag, anti-HBs の

\footnotetext{
* 信州大学第 2 内科

** エーザイ K.K.研究所, 免疫研究室

*** 自治医科大学予防生態
} <受付日 51 年 5 月 7 日 $>$
Table The prevalence of Arai-antigen (a new serum-antigen) in sera of patients with various liver diseases and of blood donors (micro-Ouchterlony method)

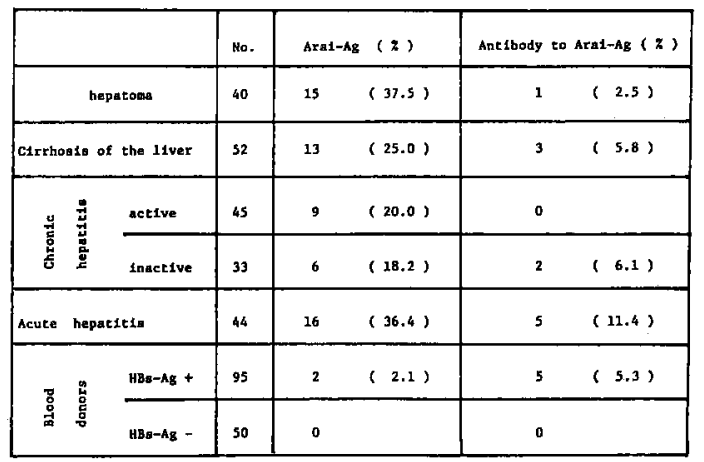

有無とは関係なく検出されたことより HBV とは直接的 関係がないものと考元られる。また本抗原は肝癌にもっ とも高率に検出されたが $\alpha \mathbf{F P}$ とは物理化学的性状を異 にしている. 今回検索した本抗原陽性の肝疾患例が必ず しも高度の黄㾝あるいは組織所見上燷死病变の著明な例 ではなく，かつ抗体も5\%前後に検出されたことより， この抗原は lipoprotein-X とも異り，また肝壊死にと もなって血中に出現する肝由来の抗原物質とす考えにく い.さらに輸血歴と本抗原, 抗体の有無との間にも一定 の関連はみられなかった.この Arai 抗原はDel Prete ら により報告された Milan 抗原 ${ }^{2}$ とは $\mathrm{CsCl}$ 中の浮上密度 が $1.08 \mathrm{~g} / \mathrm{ml}$ 以下で軽い点は類似しているが，保存による 安定性, 耐熱性, Sudan black の染色性, 抗体反応性な どの面で異っている。

以上の点より Arai 抗原は何等汃の外因性の因子によ り生体内で産生された異常りポ蛋白の一種で, 肝疾患に 伴って血中に放出，ないしは産生が充進されたものと考 えられるが，肝疾患以外にる検出される例があるのでそ の本態についてはなお今後の検討を要する。

結語：各種肝疾患，供血者に扮ける新しい血清抗原， Arai 抗原とその抗体の検出頻度を報告し考察を加えた。 索引用語 : Arai 抗原, 肝炎, 肝澏, 供血者.

文 献：1）藤松順一, 古田精市他：肝臓, 17 : 484, 1976. 2) Del Prete et al.: Lancet, 11: 292, 1970. 